\title{
Seasonal variability of ionic concentrations in surface snow and elution processes in snow-firn packs at the PGPI site on Ürümqi glacier No. 1, eastern Tien Shan, China
}

\author{
Zhongqin LI, ${ }^{1}$ Ross EDWARDS, ${ }^{2}$ E. MOSLEY-THOMPSON, ${ }^{3}$ Feiteng WANG, ${ }^{1}$ \\ Zhibao DONG, ${ }^{1}$ Xiaoni YOU, ${ }^{1}$ Huilin $\mathrm{LI}^{1}$ Chuanjin $\mathrm{LI}^{1}{ }^{1}$ Yuman $\mathrm{ZHU}^{1}$ \\ ${ }^{1}$ Key Laboratory of Cryosphere and Environment/Tien Shan Glaciological Station/Laboratory of Ice Core and \\ Cold Regions Environment, Cold and Arid Regions Environmental and Engineering Research Institute, \\ Chinese Academy of Sciences, 320 Donggang West Road, Lanzhou 730000, China \\ E-mail: lizq@Izb.ac.cn \\ ${ }^{2}$ Desert Research Institute, Raggio Parkway, Reno, NV 89512, USA \\ ${ }^{3}$ Byrd Polar Research Center, The Ohio State University, 1090 Carmack Road, Columbus, OH 43210-1002, USA
}

\begin{abstract}
To investigate the effects of both non-meltwater and meltwater-related post-depositional processes on chemical species within the snow-firn pack, a research program, the Program for Glacier Processes Investigation, was initiated in July 2002 by the Tien Shan Glaciological Station, Chinese Academy of Sciences. The seasonal variability of the ionic concentrations in surface snow samples and ion elution behavior in the snow-firn pack were assessed from surface samples collected year-round and 1011 samples collected from a snow pit at weekly intervals from September 2003 through September 2004. The results indicate that elevated ionic concentrations in spring and summer result from Asian dust-storm-derived aerosol input and other aerosols entrained in precipitation. Potential sources of these chemical species are explored using correlation and factor analyses. The elution sequence through the snow-firn pack was determined to be $\mathrm{SO}_{4}{ }^{2-}>\mathrm{Ca}^{2+}>\mathrm{Na}^{+}>\mathrm{NO}_{3}{ }^{-}>\mathrm{Cl}^{-}>\mathrm{K}^{+}>\mathrm{Mg}^{2+}>\mathrm{NH}_{4}{ }^{+}$. The elution of ions at the sampling site was found to be driven primarily by air temperature and became evident when a diurnal mean temperature of $-3.6^{\circ} \mathrm{C}$ was attained. At $0.3^{\circ} \mathrm{C}$ all of the year-round new ionic input was leached from the snow.
\end{abstract}

\section{INTRODUCTION}

Chemical records from alpine ice cores provide an invaluable source of paleoclimatic and environmental information (Thompson and others, 1995, 1998; Ginot, 2001). Not only are the atmospheric chemical composition and depositional processes recorded, but post-depositional processes within the snow/firn stratum, especially when melt occurs, are recorded as well. To investigate the effects of depositional processes and meltwater-related post-depositional processes on chemical species in the snow-firn pack, a research program, the Program for Glacier Processes Investigation (PGPI), was launched in July 2002 by the Tien Shan Glaciological Station (TGS), Chinese Academy of Sciences. An observational and experimental site (henceforth the PGPI site) was carefully located in a percolation zone of the east branch of Ürümqi glacier No. 1 (UG1) at the headwaters of the Ürümqi river at $4130 \mathrm{~m}$ a.s.l. Aerosol, surface snow and snow-pit samples were collected on a weekly basis at the PGPI site using established techniques to prevent contamination. They were then transported frozen to the TGS laboratory. At the same time, a variety of observations of the snow-firn pack physical properties and experiments on meltwater were carried out. Over the duration of the sampling campaign (September 2003-September 2004), snow-firn density and temperature were measured along a snow-pit wall, and in situ air temperature was continuously observed using a thermometer screen. Most of the samples were analyzed for major ions and insoluble microparticles, while oxygen isotopic ratios $\left(\delta^{18} \mathrm{O}\right)$, trace metals and carbonaceous particles (organic and black carbon) were analyzed for selected samples. A suite of samples was also archived (frozen) for future analyses. This study focused on both the seasonal variability of the major-ionic concentrations in surface snow and the elution processes in the snow-firn pack, and constituted a basic research component of the PGPI.

\section{METHODOLOGY}

UG1 $\left(43^{\circ} 06^{\prime} \mathrm{N}, 86^{\circ} 49^{\prime} \mathrm{E}\right)$ is located at the headwaters of the Ürümqi river in the eastern Tien Shan, central Asia, which are surrounded by vast desert areas: the Taklimakan to the south, the Gurbantunggut in the Junggar basin to the north, and the Gobi Desert to the east. With a typical continental climate, the westerly jet stream prevails across these high mountains. UG1 is a northwest-facing valley glacier composed of east and west branches covering $1.73 \mathrm{~km}^{2}$. The annual equilibrium-line altitude has averaged approximately 4055 m a.s.l. from 1959 to 2003 (Li and others, 2003), and the mean annual precipitation is about $645.8 \mathrm{~mm} \mathrm{a}^{-1}$ on the east branch (Wang and Zhang, 1985; Yang and others, 1988, 1992). The PGPI site was situated at $4130 \mathrm{~m}$ a.s.l., with no direct wintertime exposure to sunshine due to the shadowing effect of the mountain ridges. The mean annual air temperature and precipitation at the site were $-9.1^{\circ} \mathrm{C}$ and $700 \mathrm{~mm}$ w.e., respectively, during the experimental period. Maximum precipitation occurs in summer at the same time as maximum snowmelt. The floor of the snow-firn pack at this site is composed of superimposed ice that is typically formed in the glacial percolation zone or superimposed ice 
zone. The ice is characterized by clear, impermeable, opaque ice with spherical bubbles of 1-5 mm diameter. Field observations indicate that the snow depth of the percolation zone typically ranges from about $1.5 \mathrm{~m}$ in the late summer to about $3 \mathrm{~m}$ in the late spring. During winter it remains stable due to snow compaction, snowdrifting and sublimation. In the early summer, as air temperatures rise to $\sim 0^{\circ} \mathrm{C}$, the upper part of the snow layer begins to melt, leading to rapid thinning. The melt originates primarily from the accumulation received in the previous autumn. In late summer to early autumn, melting dominates and affects the entire annual layer and even the previous year's accumulation. The meltwater infiltrates the underlying firn layers, reaching the firn that overlies the impermeable ice formed in the previous year. The meltwater fills the pores of the firn and is refrozen, thus forming superimposed ice. The complete transformation of fresh snow to superimposed ice at the site took 41-47 months (You and others, 2005; Wang and others, 2006). Some of the meltwater also pooled on the surface and eventually drained away from the site.

Samples were collected weekly and every effort was made to collect fresh, well-preserved surface snow (i.e. snow not affected by post-depositional processes such as sublimation or melting) to facilitate our investigation of the seasonality in the chemical composition of both precipitation and dry deposition. During the winter season when there was insufficient snowfall, the top $3 \mathrm{~cm}$ were sampled. However, if an accumulation event occurred prior to the scheduled sampling, we collected the top $1 \mathrm{~cm}$ of fresh snow. During the summer, there was usually sufficient fresh snow available, and samples no more than 2 days old were collected from the top 3-5 cm. Over the year, a total of 54 surface snow samples were collected, but 9 samples were discarded for analysis because of problems associated with in situ melting. A pit was also sampled weekly from top to bottom at $10 \mathrm{~cm}$ increments 54 times during the year, which resulted in a total of 1011 samples. After each sampling session, the pit was refilled and then re-excavated 7 days later. The wall was then cut back by at least $50 \mathrm{~cm}$ before the next round of sample collection.

Strict procedures were followed during sampling and transportation to prevent contamination, including using disposable polyethylene gloves, oronasal masks, and precleaned polyethylene sample containers. All samples were transported frozen to the TGS laboratory. Blanks were made at each step in the process to ensure that the cumulative contamination remained below the baseline of each measured chemical species.

Samples were analyzed for major ions $\left(\mathrm{Na}^{+}, \mathrm{K}^{+}, \mathrm{Ca}^{2+}\right.$, $\mathrm{Mg}^{2+}, \mathrm{NH}_{4}^{+}, \mathrm{Cl}^{-}, \mathrm{SO}_{4}{ }^{2-}, \mathrm{NO}_{3}^{-}$and $\left.\mathrm{HCOO}^{-}\right)$by ion chromatography (Dionex DX-320), while concentrations and size distributions of insoluble microparticles were analyzed by an AccuSizer 780A (0.5-400 $\mu \mathrm{m}$ measurement range with an uncertainty $<5 \%$ ). These methods have been described by Zhao and Li (2004) and Zhu and others (2006).

\section{SEASONAL VARIATIONS OF MAJOR IONS IN SURFACE SNOW}

\section{Seasonal variability}

The major-ion concentrations and insoluble microparticles in the surface snow samples are presented in Figure 1. The ionic balances $\Delta C$ (total cation equivalents minus total

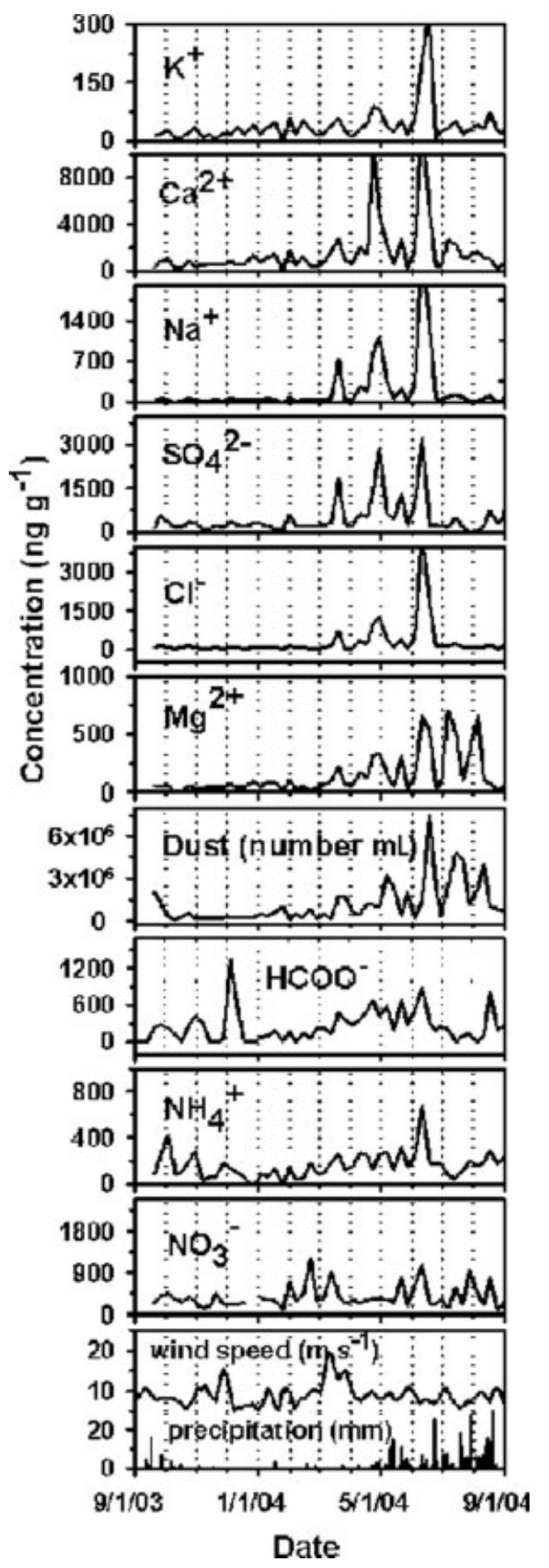

Fig. 1. Temporal variations of major ions and dust in surface snow, compared with contemporaneous precipitation and wind speed in this area. Dates are $\mathrm{m} / \mathrm{d} / \mathrm{yy}$.

anion equivalents) for the 45 samples averaged $36.1 \mu \mathrm{Eq} \mathrm{L}^{-1}$, accounting for $60 \%$ of the total anion content. Linear regression on all the samples showed that the calcium and $\Delta$ C correlate well $\left(R^{2}=0.97, N=45, p<0.01\right)$, suggesting that the $\Delta \mathrm{C}$ represents primarily the carbonate/bicarbonate in the snow (Wake and others, 1992).

The seasonal variability of the surface snow ion chemistry was found to reflect seasonal inputs of impurities from the atmosphere. Figure 1 demonstrates that $\mathrm{Cl}^{-}, \mathrm{Na}^{+}$, $\mathrm{K}^{+}, \mathrm{SO}_{4}{ }^{2-}$ and $\mathrm{Ca}^{2+}$ have similar seasonal variations, and we categorized them as group 1 . All elements in group 1 had low concentrations during the period September 2003late March 2004, and high concentrations from April throughout the summer. Group 1 profiles also contained 
Table 1. The correlation matrix for the elements in surface snow

\begin{tabular}{|c|c|c|c|c|c|c|c|c|c|c|}
\hline Element & $\mathrm{NH}_{4}^{+}$ & Dust & $\mathrm{NO}_{3}{ }^{-}$ & $\mathrm{Cl}^{-}$ & $\mathrm{SO}_{4}{ }^{2-}$ & $\mathrm{Mg}^{2+}$ & $\mathrm{Ca}^{2+}$ & $\mathrm{Na}^{+}$ & $\mathrm{K}^{+}$ & $\mathrm{HCOO}^{-}$ \\
\hline $\mathrm{NH}_{4}{ }^{+}$ & - & & & & & & & & & \\
\hline Dust & 0.36 & - & & & & & & & & \\
\hline $\mathrm{NO}_{3}{ }^{-}$ & 0.53 & 0.33 & - & & & & & & & \\
\hline $\mathrm{Cl}^{-}$ & 0.70 & 0.62 & 0.47 & - & & & & & & \\
\hline $\mathrm{SO}_{4}^{2-}$ & 0.67 & 0.56 & 0.62 & 0.78 & - & & & & & \\
\hline $\mathrm{Ca}^{2+}$ & 0.54 & 0.85 & 0.30 & 0.85 & 0.65 & 0.65 & - & & & \\
\hline $\mathrm{Na}^{+}$ & 0.65 & 0.63 & 0.32 & 0.97 & 0.72 & 0.58 & 0.89 & - & & \\
\hline $\mathrm{K}^{+}$ & 0.45 & 0.49 & 0.33 & 0.76 & 0.48 & 0.58 & 0.67 & 0.76 & - & \\
\hline $\mathrm{HCOO}^{-}$ & 0.55 & 0.38 & 0.45 & 0.50 & 0.67 & 0.20 & 0.40 & 0.41 & 0.36 & - \\
\hline
\end{tabular}

Note: The bold type indicates that the correlation is significant $(R \geq 0.7)$ at the 0.01 level (two-tailed).

sequential concentration peaks associated with precipitation events. During this period the baseline concentration of the ions rose only slightly, suggesting that the concentration increases resulted from precipitation events rather than from an increase in their atmospheric abundance. Insoluble microparticles (dust) in the samples were dominated by particles $<1.5 \mu \mathrm{m}$ in diameter. The microparticle and $\mathrm{Mg}^{2+}$ concentrations (both categorized as group 2) were highly linearly correlated $(R=0.74, N=45$, $p<0.01$; see Table 1 ) and exhibited a trend very similar to that of group 1 species before late July. However, in August there were several prominent $\mathrm{Mg}^{2+}$ and dust peaks that were absent in the concentrations of group 1 species. The concentrations of $\mathrm{NO}_{3}{ }^{-}, \mathrm{NH}_{4}{ }^{+}$and $\mathrm{HCOO}^{-}$were poorly correlated with those of the other ionic species (Fig. 1), so they were categorized as group 3. In detail, $\mathrm{NO}_{3}{ }^{-}$concentration peaks were prominent during February-March, and in June and August 2004, while relatively high $\mathrm{NH}_{4}{ }^{+}$concentrations appeared during SeptemberOctober 2003 and from spring to early summer 2004. A reduced baseline emerged during winter 2003 and persisted for much of the summer (2004). Most $\mathrm{HCOO}^{-}$and $\mathrm{NH}_{4}{ }^{+}$ peaks overlap during the study period, but a more pronounced increase of $\mathrm{HCOO}^{-}$concentration occurred

Table 2. Factor loading matrix for the elements in surface snow. Factors were extracted by principal components analysis, with varimax rotation to produce the final factor loadings. Bold type indicates the highest factor loading

\begin{tabular}{lcccc}
\hline Element & Communality & \multicolumn{3}{c}{ Factor loadings } \\
& & Factor 1 & Factor 2 & Factor 3 \\
& & & & \\
\hline $\mathrm{NH}_{4}{ }^{+}$ & 0.740 & 0.557 & $\mathbf{0 . 6 6 5}$ & 0.033 \\
$\mathrm{Dust}$ & 0.902 & 0.278 & 0.266 & $\mathbf{0 . 8 6 8}$ \\
$\mathrm{NO}_{3}{ }^{-}$ & 0.775 & -0.014 & $\mathbf{0 . 8 4 9}$ & 0.231 \\
$\mathrm{Cl}^{-}$ & 0.941 & $\mathbf{0 . 8 0 6}$ & 0.411 & 0.351 \\
$\mathrm{SO}_{4}{ }^{2-}$ & 0.828 & 0.463 & $\mathbf{0 . 7 4 2}$ & 0.250 \\
$\mathrm{Mg}^{2+}$ & 0.825 & 0.314 & 0.041 & $\mathbf{0 . 8 5 2}$ \\
$\mathrm{Ca}^{2+}$ & 0.892 & $\mathbf{0 . 6 6 8}$ & 0.241 & 0.623 \\
$\mathrm{Na}^{+}$ & 0.962 & $\mathbf{0 . 8 6 5}$ & 0.268 & 0.376 \\
$\mathrm{~K}^{+}$ & 0.711 & $\mathbf{0 . 7 5 3}$ & 0.155 & 0.346 \\
$\mathrm{HCOO}^{-}$ & 0.668 & 0.306 & $\mathbf{0 . 7 5 7}$ & 0.034 \\
Fraction of variance (\%) & 32.06 & 26.68 & 23.70 \\
\hline
\end{tabular}

during mid-March to mid-June 2004. In addition, a sharp $\mathrm{HCOO}^{-}$peak appeared in early December, coinciding with increased wind speeds.

Seasonal variability in the chemical composition of the surface snow was closely associated with climatic and environmental characteristics in the region. For example, cold frontal systems frequently sweep across the region during late March to early May (spring), producing large dust storms (Gao and others, 1992; Li and others, 1994; Wake and others, 1994). This stormy period is followed by the summer precipitation maximum (May-September) that accounts for approximately $90 \%$ of the annual precipitation. During the rest of the year, the climate regime is cold and dry. Both the spring dust storms and summer precipitation can bring terrestrial impurities to the glacier surface, as reflected by the ionic concentration profiles, especially for groups 1 and 2, in which the explicit increases during April and early May strongly coincide with the period of greatest wind intensity (Fig. 1). This suggests that the ionic concentration increases result from the input of local-to-regional dust aerosols derived by strong winds. Most concentration peaks of group 1 and 2 species overlap throughout the study period, suggesting similar transport and deposition processes. However, the amplitudes of the peaks are different, especially during the precipitation events after July 2004 (summer). As the highest concentrations coincide with the largest precipitation events, they likely result primarily from wet deposition and long-range transport to the glacier in August. The peaks of $\mathrm{Mg}^{2+}$ and insoluble microparticles in the snow samples also support this interpretation. Among the group 3 species, $\mathrm{NO}_{3}{ }^{-}$concentrations are generally out of phase with those in groups 1 and 2, indicating that it may have different source and depositional mechanisms. $\mathrm{NH}_{4}^{+}$ and $\mathrm{HCOO}^{-}$peaks slightly overlap group 1 elements (particularly with $\mathrm{K}^{+}$), but have different amplitudes.

\section{Correlation among the various chemical species}

The interrelationship of the chemical species in the snowpack was further investigated using correlation matrices (Table 1 ) and factor analysis (Table 2). Table 1 presents the matrix of $R$ values for the elements measured in the surface snow. The significant correlations ( $R \geq 0.7$, two-tailed, $p=0.01, N=45$ ) are highlighted with bold type. To connect these elements to their sources, correlations among the elements were further investigated using factor analysis (Table 2). 


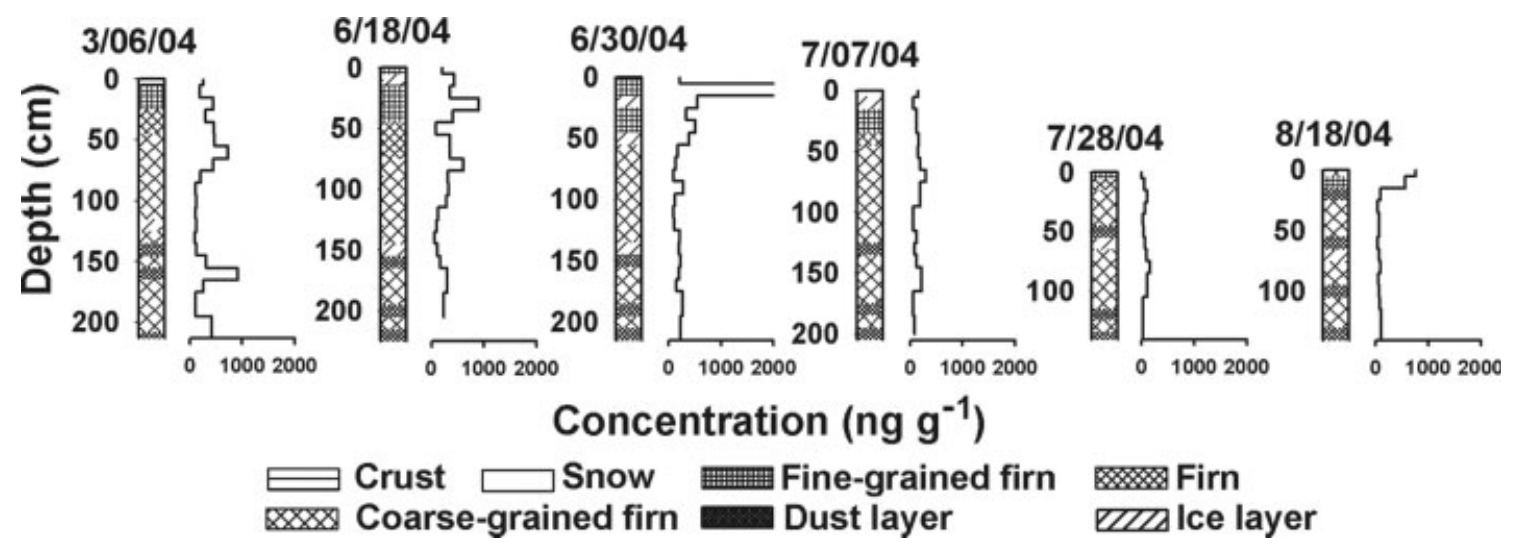

Fig. 2. Profiles illustrate the temporal variation of $\mathrm{SO}_{4}{ }^{2-}$ concentrations in the snow-firn pack at the PGPI site and confirm that they are severely modified by snowmelt during the ablation season. Dates are $\mathrm{m} / \mathrm{dd} / \mathrm{yy}$.

Factor 1 loadings are highest for $\mathrm{Cl}^{-}, \mathrm{Ca}^{2+}, \mathrm{Na}^{+}$and $\mathrm{K}^{+}$, and except for $\mathrm{SO}_{4}{ }^{2-}$ all are group 1 elements that are significantly correlated with each other. This factor is interpreted as a local-plus-regional source component. Potential sources include local mineral aerosols entrained in the atmosphere by the strong winds that prevail during spring along with a more regional Asian dust flux. Previous studies indicate that local bare rocks and glacial sediments are readily available sources for the elements in group 1 (Luo, 1983; Williams and others, 1992; Hou and Qin, 2002).

Factor 2 loadings are highest for $\mathrm{NH}_{4}{ }^{+}, \mathrm{NO}_{3}{ }^{-}, \mathrm{SO}_{4}{ }^{2-}$ and $\mathrm{HCOO}^{-}$, and except for $\mathrm{SO}_{4}{ }^{2-}$ all are group 3 elements that are also correlated with each other. This factor is interpreted as an anthropogenic source component that includes emissions from fossil fuel combustion and biomass burning, livestock manure, and commercial and natural fertilizers. Mineral dust commonly acts as a carrier for these pollutants ( $\mathrm{Li}$ and others, 1995, 1999). Although the region is relatively unpopulated, UG1 is situated only $105 \mathrm{~km}$ from Ürümqi, the provincial capital of Xinjiang Uyger Autonomous Region, with more than two million inhabitants. Also the town of Houxia is only $50 \mathrm{~km}$ away in the Ürümqi river valley. In addition, the Ürümqi-Koehler road passes only a few kilometers from the study site. We suspect that these sources must be largely responsible for the anthropogenically derived compounds deposited on the glacier. Atmospheric pollutants from Ürümqi may be transported to the glacier by the low-level regional atmospheric circulation. Clouds from the factories in Houxia drift into the river valley and periodically reach UG1 by the valley winds (Wake and others, 1992; Lee and others, 2003).

Factor 3 loadings are highest for $\mathrm{Mg}^{2+}$ and dust content (group 2), and the two elements are also significantly linearcorrelated ( $R=0.74$, two-tailed, $p=0.01, N=45$; see Table 1). This factor is interpreted as a long-distance source component, mainly deposited by wet deposition. Potential sources for this group are mineral dust and evaporite aerosols entrained along the trajectory of the air masses that bring moisture to the region.

Evidently, $\mathrm{Ca}^{2+}$ and $\mathrm{SO}_{4}{ }^{2-}$ have more potential sources than other species, making it difficult to attribute them to a particular group. Within group $1, \mathrm{Ca}^{2+}$ was highly correlated with the elements in group 2 and had a very high loading (0.623) on factor 3 , indicating that the long-distance sources are also a major contributor. The position of the Tien Shan relative to the large desert basins with predominantly calcareous material (Dregne, 1968) provides strong evidence for a desert dust source for $\mathrm{Ca}^{2+}$. In addition to its anthropogenic sources, $\mathrm{SO}_{4}{ }^{2-}$ can be widely derived from terrestrial materials (e.g. pyrite minerals and evaporates) on local and regional scales. A documented record of $\mathrm{SO}_{4}{ }^{2-}$ in an ice core from UG1 demonstrates that natural sources associated with mineral dust aerosols are basic contributors of $\mathrm{SO}_{4}{ }^{2-}$ in snow, but anthropogenic sources also have a large impact on the snow chemistry (TGS, unpublished data).

\section{ELUTION PROCESS}

For most low- to mid-latitude mountain glaciers, snow transforms to ice through infiltration and refreezing processes. Specifically, meltwater infiltrates downward to the bottom of a snowpack where it refreezes as infiltration ice in the percolation zone (Shumskii, 1964; Paterson, 1994). As the meltwater percolates vertically, elution occurs and the chemical species within the firn are redistributed by differential transportation toward the base of the snowpack. If temperatures at the snowpack floor are sufficiently cold, the chemical species can be sequentially incorporated into the infiltration ice. This is called the elution process. Under certain conditions, this depositional sequence may be preserved in the glacier; otherwise, the chemical record is destroyed by percolation. Due to elution, the original chemical composition of the snowpack is altered. Previous studies suggest that the elution effect homogenizes the snow chemistry and reduces the resolution of the ice-core record, thereby diminishing the value of alpine ice-core studies Johannessen and Henriksen, 1978; Brimblecombe and others, 1985, 1987; Bales and others, 1989; Hewitt and others, 1991). Figure 2 demonstrates the modification of the $\mathrm{SO}_{4}{ }^{2-}$ concentration profile by snowmelt at the PGPI site during the ablation season. As this is a typical result of the elution effect, the PGPI has focused much attention on this process.

\section{Elution sequence}

As described in various field and laboratory studies, ions are leached from snow and firn with different efficiencies, and the elution sequence can be determined by comparing the concentration ratios between different ions (Brimblecombe and others, 1987; Tranter and others, 1992; Eichler and others, 2001; lizuka and others, 2002). Figure 3 presents variations of $\mathrm{Mg}^{2+}, \mathrm{NO}_{3}{ }^{-}$and $\mathrm{SO}_{4}{ }^{2-}$ that provide examples 


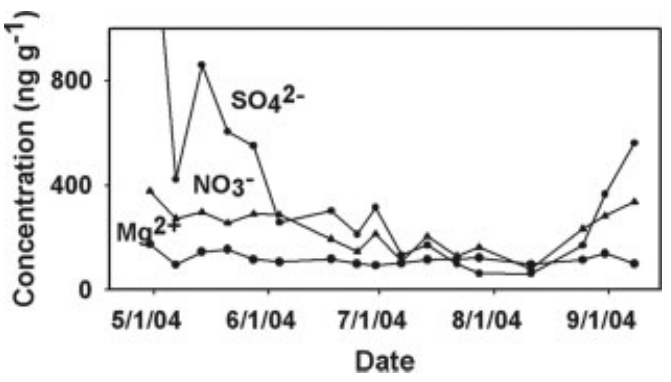

Fig. 3. Concentration variations of $\mathrm{Mg}^{2+}, \mathrm{NO}_{3}{ }^{-}$and $\mathrm{SO}_{4}{ }^{2-}$ during the ablation season. Dates are $\mathrm{m} / \mathrm{d} / \mathrm{yy}$.

of ionic concentration changes in the snow-firn pack. As explicit changes occurred from 24 April to 25 June 2004, this was selected as the study period. In the summer ablation season, all ions reached their lowest concentrations and thereafter remained stable until late August. Compared with other ions, $\mathrm{Mg}^{2+}$ demonstrated very little variation over this interval (Fig. 3), indicating that it was leached less efficiently from the snow. Therefore $\mathrm{Mg}^{2+}$ was selected as the reference species for determining the elution sequence.

The temporal variation of the ratio between the concentration of each ion, relative to that of $\mathrm{Mg}^{2+}$, is shown in Figure 4 along with the linear trend. The slopes of the linear regression reflect the relative preferences of the ions to $\mathrm{Mg}^{2+}$ during the elution process. Thus, by comparing these slopes, the following elution sequence was obtained: $\mathrm{SO}_{4}{ }^{2-}>\mathrm{Ca}^{2+}>\mathrm{Na}^{+}>\mathrm{NO}_{3}{ }^{-}>\mathrm{Cl}^{-}>\mathrm{K}^{+}>\mathrm{Mg}^{2+}>\mathrm{NH}_{4}{ }^{+}$, which is generally in good agreement with previous studies (e.g. Brimblecombe and others, 1985, 1987; Tranter and others, 1992; Hou, 2000). The elution preference varies depending on specific characteristics of the chemical species, such as

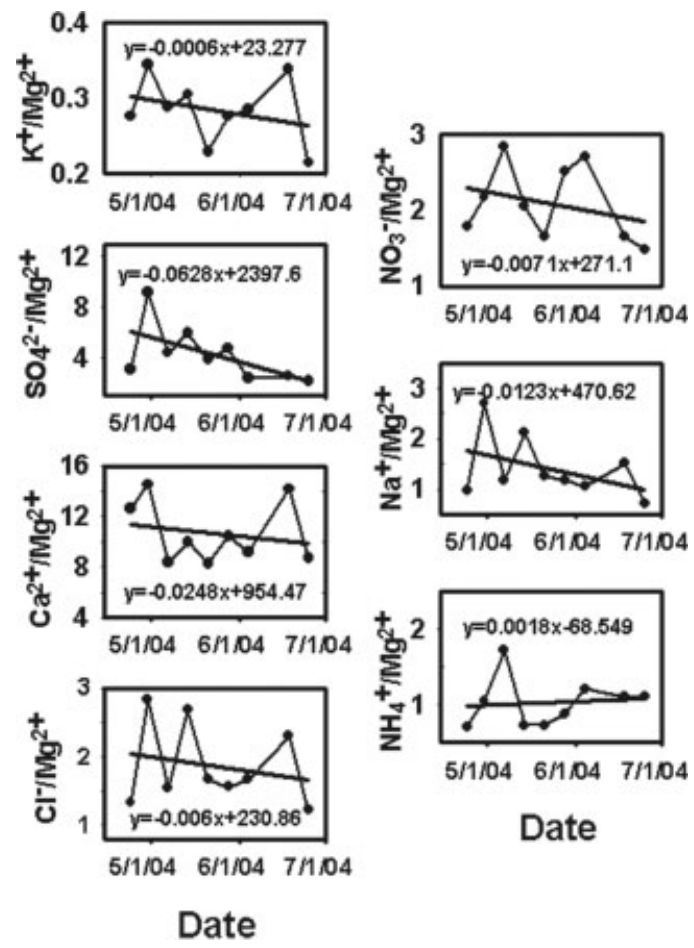

Fig. 4. Temporal variations of the ratios of $\mathrm{Ca}^{2+}, \mathrm{Na}^{+}, \mathrm{K}^{+}, \mathrm{NH}_{4}{ }^{+}, \mathrm{Cl}^{-}$, $\mathrm{SO}_{4}{ }^{2-}$ and $\mathrm{NO}_{3}{ }^{-}$relative to $\mathrm{Mg}^{2+}$ are shown along with their linear trend. Dates are $\mathrm{m} / \mathrm{d} / \mathrm{yy}$.

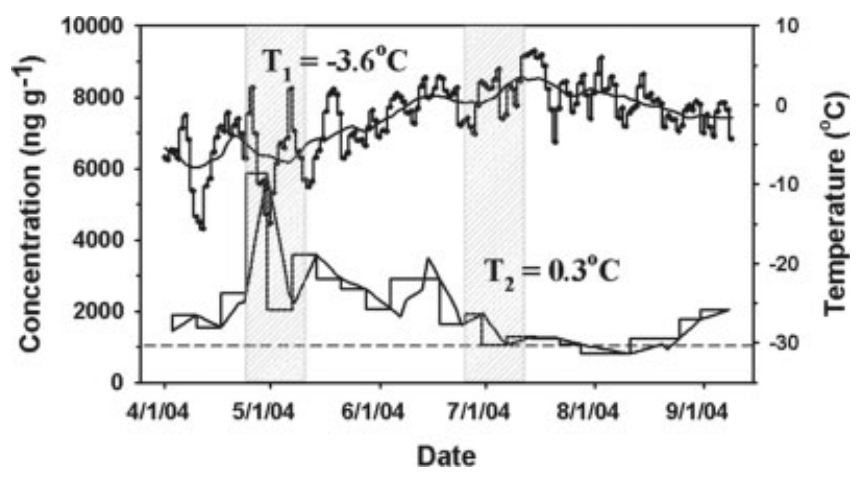

Fig. 5. Comparison of the total ionic concentrations (TIC) in snowfirn pack and in situ diurnal mean temperature. Left shaded column designates the time elution started, where the diurnal mean temperature was about $-3.6^{\circ} \mathrm{C}$. Right shaded column designates the time TIC reached its lowest value in the previous year, indicated by the dashed line, where the diurnal mean temperature was about $0.3^{\circ} \mathrm{C}$. Dates are $\mathrm{m} / \mathrm{d} / \mathrm{yy}$.

the initial concentration in the snow, the rearrangement processes during snow metamorphism, the capability to form volatile compounds, and the solubility in firn. As in many studies, $\mathrm{NH}_{4}{ }^{+}$was found to be relatively immobile with respect to the percolating meltwater and thus it is placed at the end of the elution sequence. This observation likely reflects the fact that $\mathrm{NH}_{4}{ }^{+}$is incorporated into the ice lattice (it is highly soluble in ice) as noted by Eichler and others (2001). As noted earlier, $\mathrm{Mg}^{2+}$ also is relatively immobile. The strong correlation between the concentration peaks in $\mathrm{Mg}^{2+}$ and dust layers in the 54 successive pit profiles suggests that much of the $\mathrm{Mg}^{2+}$ is bound to the surface of the dust particles so that it is less susceptible to leaching during elution than other cation species that are located at ice grain boundaries and thus more easily washed out by meltwater. However, future studies are needed for a better explanation of the elution processes.

\section{Relationship between the elution process and air temperature}

Temperature can be used as a predictor for the elution process in many cases. Quantifying the linkage between the elution process and in situ air temperature has the potential to provide a useful tool for evaluating the effect of elution, and thus for assessing ice-core quality over a wide range of locations. The magnitude of elution can be presented by variations in the total ionic concentration (TIC) of the snowfirn pack. TIC was acquired at weekly intervals by accumulating mass-weighted mean concentrations of all major ions in the snow-firn pack. A lower TIC indicates that more of the snow's chemical burden is leached out, thus reflecting intensive elution. The converse also holds. The value of TIC at the end of the 2003 ablation season (around mid-August) was $985 \mathrm{ngg}^{-1}$ (dashed line in Fig. 5). It increased gradually during winter 2003, and then rose rapidly during spring 2004. The TIC values peaked in early May, reaching a maximum of $5883 \mathrm{ng} \mathrm{g}^{-1}$. The corresponding diurnal mean air temperature at the turning point was approximately $-3.6^{\circ} \mathrm{C}\left(T_{1}\right)$. As temperature continued to rise, TIC continued to decrease, and around early July it was approaching the lowest value of the previous year, suggesting that all ionic inputs since the previous fall were completely leached out by elution. The corresponding temperature at this 


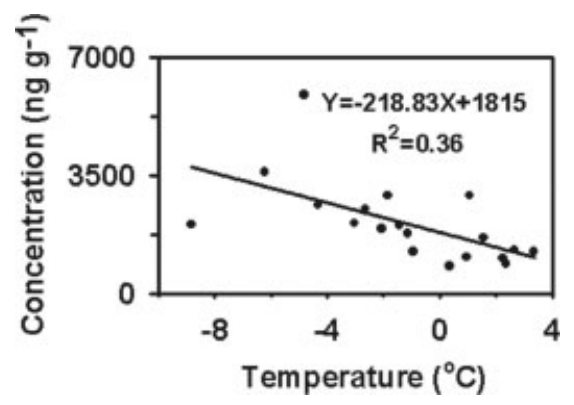

Fig. 6. The relationship between $\mathrm{TIC}$ in the snow-firn pack and diurnal mean temperature during the ablation period.

point $\left(T_{2}\right)$ was approximately $0.3^{\circ} \mathrm{C}$. All relevant data discussed above are presented in Figure 5. $T_{1}$ and $T_{2}$ are suggested to be important reference temperatures for elution at the PGPI site, such that elution started when the diurnal mean temperature reached $-3.6^{\circ} \mathrm{C}$, but when the temperature rose to $0.3^{\circ} \mathrm{C}$, all new, year-round ionic inputs were leached out of the snow. The TIC has a general inverse correlation with air temperature $\left(R^{2}=0.36, N=19, P<0.01\right)$ during the elution period, which is evident in Figure 6.

\section{CONCLUSIONS}

From this investigation we conclude that the major ions in UG1 snow can be categorized into three groups based on their seasonal behavior and characteristic relationships that were explored using correlation and factor analysis. The potential sources for these groups were identified as Earth surface materials at the local to regional scale, long-distance sources (primarily Asian dust storms) and anthropogenic sources. Some elements, such as $\mathrm{Ca}^{2+}$ and $\mathrm{SO}_{4}{ }^{2-}$, appear to have multiple sources. Secondly, the elution sequence, $\mathrm{SO}_{4}{ }^{2-}>\mathrm{Ca}^{2+}>\mathrm{Na}^{+}>\mathrm{NO}_{3}{ }^{-}>\mathrm{Cl}^{-}>\mathrm{K}^{+}>\mathrm{Mg}^{2+}>\mathrm{NH}_{4}{ }^{+}$, was determined by comparing the temporal trends in their concentration ratio relative to $\mathrm{Mg}^{2+}$. Quantitative analysis of the relationship between in situ air temperature and total ionic concentration in snow-firn pack at the study site revealed that elution is initiated when the diurnal mean temperature reaches about $-3.6^{\circ} \mathrm{C}$. When the temperature rises above $0.3^{\circ} \mathrm{C}$, all the new, year-round ionic inputs are leached from the snow.

\section{ACKNOWLEDGEMENTS}

This research was supported by the National Natural Science Foundation of China (40371028; 40571033; 40121101; J0130084), the Chinese Academy of Sciences (CAS) and the Cold and Arid Regions Environmental and Engineering Research Institute (2003101; 2004102; kzcx3-sw-341; 052062). We also thank M. Bender and two anonymous reviewers for useful comments and helpful suggestions. Support for this research has been provided under the Program for Glacier Processes Investigation (PGPI) conducted by the Tien Shan Glaciological Station, CAS.

\section{REFERENCES}

Bales, R.C., R.E. Davis and D.E. Stanley. 1989. Ion elution through shallow homogeneous snow. Water Resour. Res., 25(8), 1869-1877.
Brimblecombe, P., M. Tranter, P.W. Abrahams, I. Blackwood, T.D. Davies and C.E. Vincent. 1985. Relocation and preferential elution of acidic solute through the snowpack of a small, remote, high-altitude Scottish catchment. Ann. Glaciol., 7, 141-147.

Brimblecombe, P., S.L. Clegg, T.D. Davies, D. Shooter and M. Tranter. 1987. Observations of the preferential loss of major ions from melting snow and laboratory ice. Water Res., 21(10), 1279-1286.

Dregne, H.E. 1968. Surface material of desert environments. In McGinnies, W.G., B.J. Bram and P. Paylore, eds. Deserts of the world. Tucson, AZ, University of Arizona Press, 287-377.

Eichler, A., M. Schwikowski and H.W. Gäggeler. 2001. Meltwaterinduced relocation of chemical species in Alpine firn. Tellus, 53B(2), 192-203.

Gao, Y., R. Arimoto, M.Y. Zhou, J.T. Merrill and R.A. Duce. 1992. Relationships between the dust concentrations over eastern Asia and the remote north Pacific. J. Geophys. Res., 97(D9), 9867-9872.

Ginot, P. 2001. Glaciochemical study of ice cores from Andean glaciers. (PhD thesis, University of Bern.)

Hewitt, A.D., J.H. Cragin and S.C. Colbeck. 1991. Effects of crystal metamorphosis on the elution of chemical species from snow. Proceedings of the 48th Annual Eastern Snow Conference. Guelph, Ont., Eastern Snow Conference, 1-10.

Hou, S. 2000. Preliminary results of ion elution experiments of winter snow at the headwaters of the Ürümqi river. J. Glaciol. Geocryol., 22(4), 362-365. [In Chinese with English abstract.]

Hou, S. and D. Qin. 2002. The effect of postdepositional process on the chemical profiles of snow pits in the percolation zone. Cold Reg. Sci. Technol., 34(2), 111-116.

lizuka, Y., M. Igarashi, K. Kamiyama, H. Motoyama and O. Watanabe. 2002. Ratios of $\mathrm{Mg}^{2+} / \mathrm{Na}^{+}$in snowpack and an ice core at Austfonna ice cap, Svalbard, as an indicator of seasonal melting. J. Glaciol., 48(162), 452-460.

Johannessen, M. and A. Henriksen. 1978. Chemistry of snow meltwater: changes in concentration during melting. Water Resour. Res., 14(4), 615-619.

Lee, X., D. Qin, G. Jiang, K. Duan and H. Zhou. 2003. Atmospheric pollution of a remote area of Tianshan Mountain: ice core record. J. Geophys. Res., 108(D14), 4406. (10.1029/ 2002JD002181.)

Li, Z., T. Yao and Z. Xie. 1994. Modern atmospheric records in Guliya Ice Cap of Qingzang (Tibet) Plateau. Chinese Sci. Bull., 40(10), 874-875.

Li, Z., T. Yao and Z. Xie. 1995. Study on $\mathrm{SO}_{4}{ }^{2-}$ and $\mathrm{NO}_{3}{ }^{-}$in atmospheric aerosol. Adv. Geosci., 10(1), 289-295. [In Chinese.]

Li, Z., G. Lu, B. Liu and H.Y. Fu. 1999. Ice core of dust particulate by XPS-SEM/EDAX - impact on $\mathrm{SO}_{4}{ }^{2-}$ and $\mathrm{NO}_{3}{ }^{-}$record in ice cores. Chinese Sci. Bull., 44(15), 1424-1427.

Li, Z., T. Han, Z. Jing, H. Yang and K. Jiao. 2003. A summary of 40-year observed variation facts of climate and Glacier No. 1 at headwater of Ürümqi River, Tianshan, China. J. Glaciol. Geocryol., 25(2), 117-121. [In Chinese.]

Luo, H. 1983. Hydrochemical features of the Glacier No. 1 in the source region of Ürümqi River, Tian Shan. J. Glaciol. Geocryol., 5(2), 55-64. [In Chinese with English abstract.]

Paterson, W.S.B. 1994. The physics of glaciers. Third edition. Oxford, etc., Elsevier.

Shumskii, P.A. 1964. Principles of structural glaciology. New York, Dover Publications.

Thompson, L.G. and 6 others. 1995. A 1000 year climatic ice-core record from the Guliya ice cap, China: its relationship to global climate variability. Ann. Glaciol., 21, 175-181.

Thompson, L.G. and 11 others. 1998. A 25,000-year tropical climate history from Bolivian ice cores. Science, 282(5395), 1858-1864.

Tranter, M., S. Tsiouris, T.D. Davies and H.G. Jones. 1992. Laboratory investigation of the leaching of solute from snowpack by rainfall. Hydrol. Process., 6(2), 169-178. 
Wake, C.P., P.A. Mayewski, P. Wang, Q. Yang, J. Han and Z. Xie. 1992. Anthropogenic sulfate and Asian dust signals in snow from Tien Shan, northwest China. Ann. Glaciol., 16, $45-52$.

Wake, C.P., P.A. Mayewski, Z. Li, J. Han and D. Qin. 1994. Modern eolian dust deposition in central Asia. Tellus, 46B(3), 220-233.

Wang, D. and P. Zhang. 1985. On the valley climate of Ürümqi River in the Tianshan Mountains. J. Glaciol. Geocryol., 7(3), 239-248. [In Chinese with English abstract.]

Wang, F., Z. Li, X. You and C. Li. 2006. Snow to ice evolution process observation and study at percolation zone on Glacier No. 1 at Ürümqi river head, the East Tianshan, China. J. Glaciol. Geocryol. 28(1), 45-53. [In Chinese.]

Williams, M.W., K.A. Tonnessen, J.M. Melack and D. Yang. 1992. Sources and spatial variation of the chemical composition of snow in the Tien Shan, China. Ann. Glaciol., 16, 25-32.
Yang, D., T. Jian, Y. Zhang and E. Kang. 1988. Analysis and correction of errors in precipitation measurement at the head of Ürümqi River, Tien Shan. J. Glaciol. Geocryol., 10(4), 384-399. [In Chinese with English abstract.]

Yang, D., E. Kang and F. Blumer. 1992. Characteristics of precipitation in the source area of the Ürümqi River Basin. J. Glaciol. Geocryol., 14(3), 258-266. [In Chinese with English summary.]

You, X., Z. Li and F. Wang. 2005. Study on time scale of snow-ice transformation through snow tracing method - take Glacier No. 1 at the headwaters of Ürümqi River as an example. J. Glaciol. Geocryol., 27(6), 853-860. [In Chinese.]

Zhao, Z. and Z. Li. 2004. Determination of soluble ions in atmospheric aerosol by ion chromatography. Mod. Sci. Instrum., 5, 46-49. [In Chinese.]

Zhu, Y., Z. Li and X. You. 2006. Application and technique in glacier by AccuSizer 780A Optical Particle Sizer. Mod. Sci. Instrum., 3, 81-84. [In Chinese.]. 